\title{
COMMON SCHOOL TEXTS \\ IN USE IN UPPER CANADA PRIOR TO 1845*
}

The whole question of the use of foreign textbooks in the schools of Canada is of long standing. Currently a great deal of attention has been focussed on the so-called American domination of the Canadian publishing industry and the influence such predominance allegedly exerts in the matter of Canadian textbooks in the English language. ${ }^{1} \mathrm{~A}$ former Ontario MLA, Mr Tim Reid, reported recently that the percentage of new textbooks of Canadian origin being adopted for use in schools across Canada was decreasing - from 77\% in 1965 to 69\% in 1966 to 59\% in 1967 . He estimated that the current figure might well be below $50 \%{ }^{2}$ Such extensive use of non-Canadian, mainly American, books in Canadian schools, it is argued, serves very poorly any efforts to inculcate in today's youth knowledge about Canada, not to mention concepts of Canadian nationality. The branchplant nature of our economy, critics point out, is being duplicated in our educational system as well, as we become increasingly integrated in the American "knowle dge industry."

Over a century ago observers in early Ontario were expressing similar concern about the extent of American influence in the schools of Upper Canada. While attention was split between American teachers and textbooks, one can note numerous references to the widespread use of American books with their corresponding "deleterious" influence. Dr Thomas Rolph, who travelled in Upper Canada in 1832-3, said in reference to the state of schools in the province at the time:

It is melancholy to traverse the Province and go into many of the Common Schools; you will find ... historical reading books describing the American population as the most free and enlightened under heaven; insisting on the superiority of their laws and institutions to those of all the world ... and American Spelling Books, Dictionaries and Grammars, teaching them an anti-British dialect and idiom although living in a Province and being subjects of the British Crown. ${ }^{3}$

Another critic, Father Alexander Macdonell, the future Catholic bishop, who was spokesman of the Scottish Highland settlers of Glengarry County, also casti-

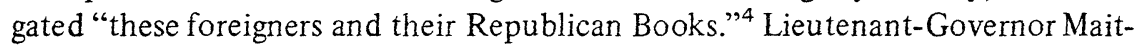
land himself referred to the "mischief [that] might result from instructions by American schoolmasters and from the use of American schoolbooks," and the Rev John Strachan feared the way American schoolbooks "breathe hatred to everything English." 5

Examples of the American schoolbooks that caused concern to Upper Canadian authorities are not hard to find. One book printed in Boston and, according to 
the local historian, J. A. Bannister, used in the District of London, included the following catechism:

Q. 'What is the best government on earth?'

A. 'A republican Government like that of the United States.'

Q. 'What is the worst government on earth?'

A. 'A Monarchical Government like that of England and Canada.'

Q. 'Will you, if occasion arises, rise up and rebel against such a government as yours, and join the States?'

A. 'Yes, with all my power and influence.' 6

Similar glorification of the United States, its people and institutions was commonly found in these textbooks. Olney's A Practical System of Modern Geography (1847), widely used in the province's schools, provides an interesting example of this inculcation of patriotism:

The United States are the most interesting and important division of the western continent. They are distinguished for the excellence of their government - the rapid increase of the population - and for the intelligence, industry and enterprise of the inhabitants.

Another geography text, Morse's Geography, was also typical of those books which devoted little space to Canada and tended to enlarge the image of the United States. In Morse, for example, the State of Rhode Island was allotted more space than Upper Canada and Lower Canada together. ${ }^{8}$ A third geography by George Van Waters spoke of the United States "as being the largest, most enlightened and powerful republic on the globe."

The reason for the prevalence of American texts was simple - the proximity of the United States. American texts were, therefore, cheaper and more readily available. In 1829 Strachan observed how difficult it was to procure textbooks in the province, particularly in the remote areas where the added factor of cost also came into play. The shortage of books generally had been noted earlier by Edward Allen Talbot, who picturesquely observed in 1824 that "the scarcity of books in the country parts of Canada is nearly as great as that of pineapples on the summit of Snowdon." 10 So in many cases American texts were used because there was nothing else to be had. David Mills (1831-1903), a federal cabinet minister under Mackenzie and Laurier, recalled that as a child in Kent County the only textbook he possessed when he started school was an American edition of Cobb's Spelling Book. ${ }^{11}$ There were only two geographies for the whole class, Olney's and Woodbridge's, both American. ${ }^{12}$

Various legislative efforts were made to improve the textbook situation. The Common School Act of 1816 authorized the District Boards of Education both to spend certain amounts in the purchase of textbooks and to distribute them. Since the legislation remained permissive, however, little came of it. Eight years 
later, the Act of 1824 provided an annual grant of $£ 150$ for the purchase of books for religious and moral instruction. The sum was to be shared equally among the Districts, and the District Boards were to supervise the selection of books.

The overall supervision of the grant, however, rested with the newly established provincial commission known as the General Board of Education. This was a project first proposed in 1822 and initiated the following year by Lieutenant-Governor Maitland in the hope of establishing a "general system" of public education for the whole province. The president of the Board was the Rev John Strachan, the leading member of the Church of England in the colony and the kingpin of the Family Compact. The Board (officially the Board of General Superintendance of Education) was charged with supervising school lands and finances, controlling teacher appointments, and choosing textbooks. Despite the Board's potential for establishing an integrated system of education for the colony, very little was accomplished to this end. Because of Strachan's insistence that education come under Church of England control, the Board proved unpopular and faced mounting attacks from the growing ranks of Reformers who objected to Tory, Anglican dominance. Moreover, Strachan himself soon after his appointment turned his attention to higher education, in particular to the problems associated with the founding of King's College at York.

The Board's minutes reveal how little of value was actually accomplished. Although it was charged with purchasing "books and tracts designed to afford moral and religious instruction," its minutes record only one authorization for common schools, Mavor's Spelling Book ${ }^{13}$ Two vociferous opponents of Strachan allude, however, to additional authorizations designed to prejudice the non-denominational nature of the common schools. The upstart Scottish journalist, William Lyon Mackenzie, objected to the "permanent public provision out of the province's funds [of $\$ 600$ a year] for purchasing Episcopalian books and tracts to convert the youth of the colony to the established faith." ${ }^{14}$ Two years later, in 1830 , he specified that a sum in excess of $£ 1000$ had been spent by the Board on Church of England catechisms and on Strachan's favorite primers. ${ }^{15}$ Thaddeus Osgood, a humanitarian reformer active in Indian education, was equally specific in his charges:

I am informed that the Dr. [Strachan] purchased six hundred copies of Dr. Bell's System of Education at one time. There being only one school of that kind in the province [presumably Upper Canada Central School at York], it is thought that so many copies of that book were not wanted. And it appears very suitable, and what might have been expected, that from a grant made from the funds of the province books suitable for all denominations of Christians would have been obtained; but those only which are peculiar to the Church of England have been obtained. ${ }^{16}$ 
The campaign against the Board finally bore fruit when the Colonial Office was persuaded to dissolve it in 1833 . No further effort to establish a system of authorized textbooks was made until Egerton Ryerson became Chief Superintendent of Schools for the province in 1846, when through the school act of that year he banned all foreign books from use in the schools.

As concern mounted about American texts, a simple solution suggested itself, namely, to publish Canadian ones to offset those from the United States. Some attempts were made in this direction as early as 1824 when a few books were printed cheaply at a press in Lanark County. ${ }^{17}$ Five years later Alexander Davidson of Port Hope completed the first copyrighted book in Upper Canada, a speller entitled The Upper Canada Spelling Book. ${ }^{18}$ Davidson's work on the book, the result of seven years' experience as a teacher, derived from his opinion that "unless some proper elementary books be got into general circulation, common school education will continue to be little better than a mere farce, and a useless expenditure of public money." 19 He noted that nine out of ten books in use were from the United States. In fact in his neighbourhood, he reported, "for several years past no English Books could be procured ... so that I am led to believe that the supply from England is precarious, and not at all equal to the growing demands of the Province." ${ }^{20}$ Davidson's continuing concern about the presence of American textbooks and a forthright appeal for spelling books of Canadian origin can be seen reflected in the Preface to the 1848 edition of his Canada Spelling Book (see the facsimile reproduction on page 40 ).

Another solution was to publish Canadian editions of respected British texts. In 1827, for example, the Kingston printer J. A. Macfarlane sought through Maitland the "patronage" of the General Board of Education in order to proceed with a new edition of Murray's English Grammar. ${ }^{21}$ The need seemed readily apparent - to Macfarlane at any rate.

The American Spelling Books, it is well known, are at present almost exclusively used in the Country, and as there are many things contained in these publications not very suitable to our Constitution and Government, it has occurred to me that an edition of some approved English work of this kind would meet with the approbation of the public....22

Three years later Macfarlane's appeal for state support was couched in different language. Now instead of inveighing against American influence he pointed out to Lieutenant-Governor Colborne the advantage of a teacher's having one grammar for a whole classroom instead of the "six or more different editions" normally found "in a school where twenty or thirty boys are studying English Grammar."23 This very notion was one of the main arguments Ryerson was to utilize two decades later in promoting the province-wide adoption of the Irish National Series.

The list that follows indicates some of the school texts in use in Upper Canada 
There is scarcely anything of so much importance to a community as a suitable SPELIING Boor ; it exerts an influence peculiarly its own, whether in regard to first impressions, or the formation of character and conduct. The sentiments acquired at school are generally retained through life.

During a residence of nearly twenty years in Canada, the compiler of the following pages often had occasion to notice the great diversity of elementary books in use, and how exceedingly inappropriate many of them were to the object for which they were professedly designed. At the present time this diversity is not diminished ; and it cannot be denied, that, in different sections of the country, those of the Uniter? States origin are the most numerous. While spelling books from England are to $u s$ necessarily defective, not being suited to our scenery and other localities, those of a foreign origin are liable to more serious objections.

It is very generally acknowledged, that our system of popular instruction is exceedingly inefficient; but were it otherwise, the evil alluded to is one of great magnitude, and is, in itself, sufficient to excite regret in the mind of every individual possessed of any degree of true patriotism.

Since no person more competent to the task. has stepped forward to apply a remedy, it has been the object of the compler to do so in the succeeding pages. In pursuit of this object-in addition to lessons written expressly - he has availed himself of every assistance within his reach. Nor has he forgotten that Education, unconnected with Religion, is vain, if not injurious; he has, therefore, been particularly careful to introduce each reading lesson as will subserve the interests of religion and morality, by directing the young mind to the great Author of all existence, and to consider itself destined to be an heir of immortality.

Niagara, 11th July, 1840. 


\section{HHE

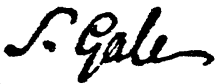 \\ TUTOR's ASSISTAN'T; \\ BEING A \\ COMPENDIUM OF ARITHMETIC, \\ AND A \\ COMPLETE QUESTION-BOOK.}

\section{CONTAINING :}

I. Arithmetic in whole Numbers; its Rules, in a new and more concise Method than any hitherto published; with an Application to each Rule, consisting of a large rariety of Questions in seal Business, with their Answers annexed.

II. Vulgar Fractions, which are ireated with a great deal of plainness and perspicuity.

III. Decimals, with the Extraction of the Square, Cube and Biquadrato Roots. after a very plain and familiar manner; in which are set down Rules for the easy calculation of Interest, $A x$ nutities, and Pensions in Ar-

rears, the present worth of $A x$ nuities, \&c. either by Simple or Compound Interest.

IV. Duodecimals or Multiplication of Feet and Inches, with Examples applied to measuring and working by Multiplication, Practice, and Decinals.

v. The Mensuration of Circles, \&e.

vI. A Collection of Questions set down promiscuously, for the greater Trial of the for:going Rules.

VII. A general Trable for the reais calculating the Intcrest of any Sum of Money, at any Rate per Cent. likewise Rents, Salaries. sc.

TO WHICH IS ADDED,

\section{AN APPENDIX \\ ON CIRCULATING DECIMALS.}

The whole being adapted either as a Question-Boak fo: the Use of Schools, or as a Remembrancer and Instirucior to such as have some Knowledge therein.

This Work hoving been perused by several eminent MaWernaticians and Accomptants, is recommended as the best Compendiu:n hitherto published, for the Use of Schools, or for Private Persons.

BY FRANCIS WALKINGAME, WRITING-NAASTER AND ACCOMPTANT.

FROM THE FIFTY-FIRST LONDON EDITION.

BONTREAL:

PRINTED RY XAYUM MOWER, 91, ST. PAUL STEET.

1518. 
before 1845 . The texts, whether Canadian or non-Canadian, are listed by subject and imprint date with a separate listing of other Canadian imprints. Every effort was made to determine exactly where and when each text was used. It is almost certain, however, that these texts were used in more districts than these columns would in dicate.

It is significant that over half the texts listed (except those under "Other Canadian Imprints") were printed in the United States. The others originated in England, Scotland, Ireland or Canada. The earliest Canadian imprint I found was Francis Walkingame's The Tutor's Assistant published in Montreal by Nahum Mower in 1818 (see title page facsimile on page 41). The popularity of Lindley Murray's Readers and Grammars and William Mavor's Spellers is clearly evident. The paucity of Latin texts is a reflection of the practice of normally restricting Latin instruction to the grammar schools; there Ruddiman's Rudiments was very popular. ${ }^{24}$

The following list was compiled, wherever possible, from direct consultation of the textbooks. Texts were found in the Library of the University of Western Ontario, the Special Collections Division of the University of British Columbia Library, the Baldwin Room of the Toronto Central Library, and the Public Archives of Ontario. In cases where a copy of a text could not be located, recourse was had to the excellent bibliography of early American textbooks in Ruth Miller Elson, Guardians of Tradition (Lincoln: University of Nebraska Press, 1964), and for a few British titles, to the British Museum, General Catalogue of Printed Books (London, 1966). Every effort was made to locate the earliest known imprint date of each text and to ascertain whether or not a foreign text had a subsequent Canadian imprint. The source for the schools where the texts were used, and when, was in large part the Educational Papers for Upper Canada in the Public Archives of Canada. ${ }^{25}$

\section{Notes}

* The author wishes to acknowledge with thanks the advice and assistance of Professors F. H. Armstrong and J. J. Talman of the Department of History, University of Western Ontario, and Mrs Anne Yandle, Special Collections Division, The Library, University of British Columbia. The two illustrations are reproduced, with kind permission, from copies in the Special Collections Division.

1 See James Lorimer, "Canadian Textbooks and the American 'Knowledge Industry'," This Magazine is About Schools, vol. v, no. 3 (summer 1971), pp. 47-57, and James Lewis and Samuel, "Why Canada's Book Publishing Industry Should be Repatriated," Canadian Dimension, vol. viII, no. 3, pp. 23-25, 48-49. 
2 As reported in University Affairs, vol. Ix, no. 9 (November 1970), p. 14.

3 Thomas Rolph, Observations Made during a Visit, in 1832, 33, Together with a Statistical Account of Upper Canada (Dundas: G. H. Hackstaff, 1836), p. 262.

4 Puhlic Archives of Canada (hereafter referred to as P.A.C.), Q Series, 321.228. Macdonell to Bathurst. January 16, 1817.

5 Public Archives of Ontario (hereafter referred to as P.A.O.), Minutes, General Board of Education. Extract of dispatch, Maitland to Bathurst, May 13, 1823; P.A.C., Upper Canada Sundries, Strachan to Maitland, March 10, 1826. Strachan's protégé and successor as Bishop of Toronto, A. N. Bethune, spoke against the presence in the schools of both American teachers and texts which "tend to insinuate the poison of disaffection." P.A.C., Educational Papers. Bethune, "Remarks on Common Schools," October 5, 1827.

6 A. Bannister, Early Educational History of Norfolk County (Toronto: University of Toronto Press, 1926), p. 46.

7 Quoted in V. E. Parvin, Authorization of Textbooks for the Schools of Ontario, 1846-1950 (Toronto: University of Toronto Press, 1965), p. 30.

8 Jedidiah Morse, Geography Made Easy ... for the Use of Schools and Academies in the United States of America 18th ed. (Boston: Thomas \& Andrews, 1816), pp. 77-82. Concerning religion in Upper Canada, Morse made the rather shocking statement that although Methodism was the prevailing religion, "for the greater part, the country is destitute of regular religious teachers, and many of the inhabitants appear to have no religion." Ibid., p. 80. Morse also incorrectly placed the capture of Quebec in 1754. Ibid., p. 81. Ryerson, however, had kind words for Morse; he termed it "the best of the kind that I have seen in any country." Canada, Journal of Legislative Assembly, vi, (1847), app. No. 2. Morse's Geography as a result, was tendered the sanction of the Council of Public Instruction despite the School Act of 1846, which banned all foreign books from use in the schools. The sanction was upheld until 1865 when the first Canadian geography appeared. J. G. Hodgins (ed.), Documentary History of Education in Upper Canada 1792-1876 (28 vols., Toronto: L. K. Cameron, 1893-1904), xIx, 67.

9 George Van Waters, The Poetical Geography Designed to Accompany Outline Maps or School Atlases to Which are Added the Rules of Arithmetic in Rhyme (Louisville, 1851). For similar examples of the inculcation of patriotism, see Ruth Miller Elson, Guardians of Tradition: American School Books of the Nineteenth Century (Lincoln, Nebraska: University of Nebraska, 1964).

10 Edward A. Talbot, Five Years' Residence in the Canadas (London: Longman, Hurst, Rees, Orme, Brown and Green, 1824), II, 90.

11 Fred Landon, London Free Press, July 9, 1838. Mills was likely referring to Cobb's Juvenile Reader, No. 1 "designed for the use of small children." Subtitled "Interesting, Moral, and Instructive Reading Lessons," Cobb's No. 1 had large print, a few illustrations, and words of one or two syllables. By contrast, Cobb's No. 3, "designed for the use of larger children," had small print, no illus- 
trations, and words of "a greater number of syllables." The two editions 1 examined were: Cobb's Juvenile Reader No. 1 (Oxford, N.Y.: Chapman \& Flagler, 1832), and Cobb's Juvenile Reader No. 3 (Sandy Hill, N.Y.: David Howland, 1838). The former carried the signature "William B.D. Clarke" and the date "Aug. 6,1843 ," but no place was mentioned.

12 I was unsuccessful in my efforts to uncover a copy of Olney's work, but I did find a fourth edition of Woodbridge: Modern School Geography on the Plan of Comparison and Classification (Hartford: Belknap and Hamersley, 1846). The subject of Canada, New Brunswick, Nova Scotia and Newfoundland was treated in three short pages, together with an illustration of the "Falls of Niagara." Besides establishing that "agriculture is not skilfully conducted" in the Canadas, Woodbridge commented: "The people of East Canada are chiefly French peasants, who are industrious, but very ignorant. West Canada is chiefly inhabited by British and Americans, who are better instructed." (p. 168).

13 P.A.o., Minutes, General Board of Education, Annual Report for 1828, p. 52. The following list of texts in use bears out the popularity of Mavor's Spelling Book.

14 Colonial Advocate, July 3, 1828.

15 Ibid., February 25, 1830.

16 P.A.C., Educational Papers. Osgood to Colborne, December 9, 1828.

17 P.A.o., Colonial Correspondence, I. R. Nelson Mason to Glasgow Colonial Society, July 17, 1824. Cited in J. J. Talman, "Social Conditions in Upper Canada, 18151840 " (Ph.D. thesis, University of Toronto, 1930), p. 168. It is perhaps significant that the first paper produced in Upper Canada appeared about the same time - in 1826. See Nina L. Edwards, "The Establishment of Papermaking in Upper Canada," Ontario History, XXXIX (1947), pp. 63-74. For a more recent account, see J. A. Blyth, "The Development of the Paper Industry in Old Ontario, 1824-1867," Ontario History, LxII, no. 2 (June, 1970), pp. 119-133.

18 See W. R. Riddell, "The First Copyrighted Book in the Province of Canada," Ontario Historical Society: Papers and Records, Xxv (1929), p. 405.

19 P.A.C., Upper Canada Sundries, Davidson to Hillier, July 23, 1828.

20 Ibid., June 2, 1828.

21 P.A.C., Educational Papers. Macfarlane to Hillier, September 1, 1827. I could not find a copy of Murray's Grammar, but there was an edition of his English Reader published in Montreal in 1824 by Whiting and Mower. Certainly the popularity of Murray's books is attested to by reference to the following list. A Toronto edition of The English Reader was finally published in 1838 by Robert Stanton, and the following year an Introduction to the English Reader by Lindley Murray was published in Toronto by Eastwood and Company. (The copy of the Introduction I consulted was sold by T. A. Harton, "dry goods, groceries, boots, shoes," of Newmarket.) Murray claimed The English Reader was "designed to assist young persons to read with propriety and effect; to improve their language and senti- 
ments, and to inculcate some of the most important principles of piety and virtue." (See title page, 1824 edition) A tall order, but nevertheless one held to be attainable by educators of the day, for as children learned to spell and read they were supposed to imbibe good moral lessons as well.

22 P.A.C., Educational Papers. Prospectus seeking response to such a printing, June $18,1827$.

23 P.A.C., Educational Papers. Macfarlane to Colborne, November 20, 1832.

24 See F. H. Armstrong, "Latin in Nineteenth-Century Ontario: Canon Scadding's Latin Textbooks," Echos du monde classique/Classical News and Views, xII, no. 1 (January, 1969), pp. 1-10.

25 Readers are invited to send to the author any corrections or additions that might contribute to a more complete and accurate list.

Common School Texts in Use in Upper Canada

\begin{tabular}{lll}
\hline Text (by imprint date) & Schools Where Used & $\begin{array}{c}\text { Dates } \\
\text { in Use }\end{array}$ \\
\hline
\end{tabular}

ARITHMETICS

1784 Dilworth, Thomas.

Montague (Johnstown

The Schoolmaster's Assistant

District)

New York: Hugh Gaines,

Norfolk

1784.

1791 Melrose, A.

Lochiel, Div. \#1

1842

A Concise System of Arithmetic.

Edinburgh, 1791.

1795 Pike, Nicholas.

Abridgement of the New and

Norfolk

1828

Complete System of Arithmetic

Composed for the Use and

Adapted to the Commerce of

the Citizens of the United States.

Worcester, Mass.: Isiah Thomas, 1795.

1800 Daboll, Nathan.

Gore

1831

Schoolmaster's Assistant. New

London

1831

London, Conn.: Samuel Green,

London

1835

1800 .

Wentworth County

Johnstown

1838

McCaul Commission

1839

Norfolk

1828

Prince Edward

1838 
Leominster, Mass.: Adams and Wilder, 1802.

1802 Hamilton, Robert. An Introduction to Merchandize.

5 th ed. Edinburgh: Murray \& Colborne, 1802.

1809 Hutton, Charles. A Complete Treatise on Practical Lochiel, Div. \#1 Arithmetic and Bookkeeping... Adapted to the Use of Schools and Men of Business in the United States. New York: W. Elliot, 1809.

1818 Walkingame, Francis.

The Tutor's Assistant. Montreal: Nahum Mower, 1818.

1826 Colburn, Warren. A Introduction to Algebra upYork County 1829

Kitley 1819

London 1832

London

Wentworth County 1835 Middlesex County ? Raleigh Township 1845 Lochiel Div. \#1 1842 Matilda, School \#1 1842 Johnstown 1842 Prince Edward 1838 Newcastle 1838 Middlesex County 1838 on the Inductive Method of Instruction. Boston: Hilliard, Gray, Little and Wilkins, 1826.

1841 Willets, Jacob. The Scholar's Arithmetic; Designed for the Use of Schools in the United States. 45th ed. Poughkeepsie, N.Y.: W. Wilson, 1841. 


\section{ARITHMETICS}

1842 Gouinlock, G. and J.

A Complete System of Practical

Arithmetic; for the Use of

Schools in British North

America. Hamilton: J. Ruthven, 1842.

1862 Greenleaf, Benjamin.

A Mental Arithmetic, upon the

Inductive Plan. Boston: Davies, 1862.

\section{Other Canadian Imprints}

1844 Walkingame, Francis. The Tutor's Assistant. Montreal: Armour and Ramsay, 1844.

1849 Walkingame, Francis. The Tutor's Assistant: Being a Compendium of Arithmetic, Adapted to the Use of Schools in Canada. Second Canadian from the 76 th London ed. Picton: J. McDonald, 1849.

\section{GRAMMARS}

1821 Murray, Lindley.

Gore

English Grammar .... Dublin:

John Cumming, 1821.

\section{Kitley}

London

1835

Ottawa District

1818

Township of Chatham

County of York

1825 Murray, Lindley.

Middlesex County

McCaul Commission

English Grammar, Adapted to the Different Classes of Learners

Norfolk County

.... Cooperstown, N.Y.: H. and

E. Phinney, 1825.

Johnstown

Prince Edward

1838

Ottawa

1838

London

1838

Bathurst

1838

1838

1824 Blair, Hugh.

Newcastle

1825

An Abridgement of Lectures on

Norfolk

Rhetoric. Brattleborough: Holbrook and Fessenden, 1824. 
Text (by imprint date)

Schools Where Used

Dates

GRAMMARS

1831 Kirkham, Samuel.

Middlesex County 1845

English Grammar in Familiar

McCaul Commission

1839

Lectures. Rochester: Marshall

Dean, 1831.

Howard Township School

- Talbot Road

1842

Prince Edward

1838

1834 Lennie, William.

Middlesex County

1845

The Principles of English Grammar. $19^{\text {th }}$ ed. Montreal: A. Bow-

Prince Edward 1838 man, 1834.

\section{Other Canadian Imprints}

1835 Murray, Lindley. An Abridgement of Murray's English Grammar. Montreal: J. and T. A. Starke, 1835.

1843 Murray, Lindley. English Grammar . . . 25 th ed. Montreal: Armour and Ramsay, 1843.

1845 Kirkham, Samuel. English Grammar in Familiar Lectures. Toronto: Richard Brewer, 1845.

1849 Lennie, William. The Principles of English Grammar. 23 ${ }^{\text {rd }}$ Edinburgh ed. Toronto: Brewer McPhail, 1849.

READERS

1796 Bingham, Caleb.

The American Preceptor. Boston:

Manning and Loring, 1796.

1798 Enfield, William.

The Speaker: or, Miscellaneous

Pieces, Selected from the Best

English Writers. Hudson, N.Y.:

Ashbel Stoddard, 1798.

Montague (Johnstown

District)

Newcastle

1823

Newcastle

1825

Gore

1831

Norfolk

1828

1803 Murray, Lindley.

Ottawa District

1818

The English Reader: or, Pieces

in Prose and Poetry. Boston:

Newcastle

1823

Newcastle

1825

E. Larkin, 1803

County of York

1829

Lochiel Div. \#1

1835

London

1832 


\begin{tabular}{|c|c|c|}
\hline Text (by imprint date) & Schools Where Used & $\begin{array}{l}\text { Dates } \\
\text { in Use }\end{array}$ \\
\hline \multicolumn{3}{|l|}{ READERS } \\
\hline 1803 Murray, Lindley (cont'd) & $\begin{array}{l}\text { London } \\
\text { London } \\
\text { McCaul Commission } \\
\text { Montague } \\
\text { Middlesex County } \\
\text { Rawleigh Township } \\
\text { Matilda School \#1 } \\
\text { Murray } \\
\text { Howard Township, } \\
\text { Talbot Road } \\
\text { Prince Edward } \\
\text { Bathurst } \\
\text { Newcastle } \\
\text { Western } \\
\text { Norfolk County }\end{array}$ & $\begin{array}{l}1842 \\
1817 \\
1839 \\
1839 \\
1845 \\
1842 \\
1842 \\
1842 \\
\\
1842 \\
1838 \\
1838 \\
1838 \\
1838 \\
1828\end{array}$ \\
\hline $\begin{array}{l}1836 \text { Chambers, William and } \\
\text { Robert (eds.). } \\
\text { Chambers'Educational Course. } \\
\text { Edinburgh: W. and R. Chambers, } \\
1836\end{array}$ & Middlesex County & 1845 \\
\hline $\begin{array}{l}\text { n.d. Scott, Lessons in Reading for } \\
\text { the Improvement of Youth, } \\
\text { n.d. }\end{array}$ & $\begin{array}{l}\text { Newcastle } \\
\text { Newcastle } \\
\text { Norfolk }\end{array}$ & $\begin{array}{l}1823 \\
1825 \\
1838\end{array}$ \\
\hline
\end{tabular}

\section{Canadian Imprints}

1824 Murray, Lindley. The English Reader. Montreal: Whiting and Mower, 1824. 1832 Murray, Lindley. Introduction to the English Reader. Hallowell: Joseph Wilson, 1832.

1835 Murray, Lindley. The English Reader. Toronto: E. Lesslie \& Sons, 1835.

1838 Murray, Lindley. The English Reader. Toronto: Robert Stanton, 1838.

1839 Murray, Lindley.Introduction to the English Reader. Toronto: Eastwood \& Co., 1839. 
1791 Vyse, Charles.

Norfolk County

1828

The New London Spelling-Book. $10^{\text {th }}$ ed. London, 1791.

1799 Fenning, Daniel.

The Universal Spelling Book.

Norfolk County

1828

Philadelphia: G. Douglas, 1799.

1804 Murray, Lindley. An English Spelling Book. York [Eng.], 1804.

Gore

1831

Ottawa District 1818

Kitley 1819

Norfolk County 1828

1806 Mavor, William.

The English Spelling-Book.

Glasgow and London:

Cameron and Ferguson, 1806.

Newcastle 1825

Newcastle 1838

York County 1829

Gore 1831

London $\quad 1832$

London 1839

London 1838

Middlesex County 1845

McCaul Commission $\quad 1839$

Raleigh Township $\quad 1842$

Lochiel, Div. \#1 1842

Matilda School \#1 1842

Murray 1842

Howard Township, Talbot Road 1842

Norfolk County 1828

Johnstown 1838

Bathurst 1838

Prince Edward 1838

Ottawa 1838

Western 1838

1810 Webster, Noah, Jr.

Ottawa 1818

American Spelling Book.

Boston: John West, 1810.

Newcastle

1825

Gore 1831

Kitley 1819

Montague (Johnstown

District)

Wentworth County 


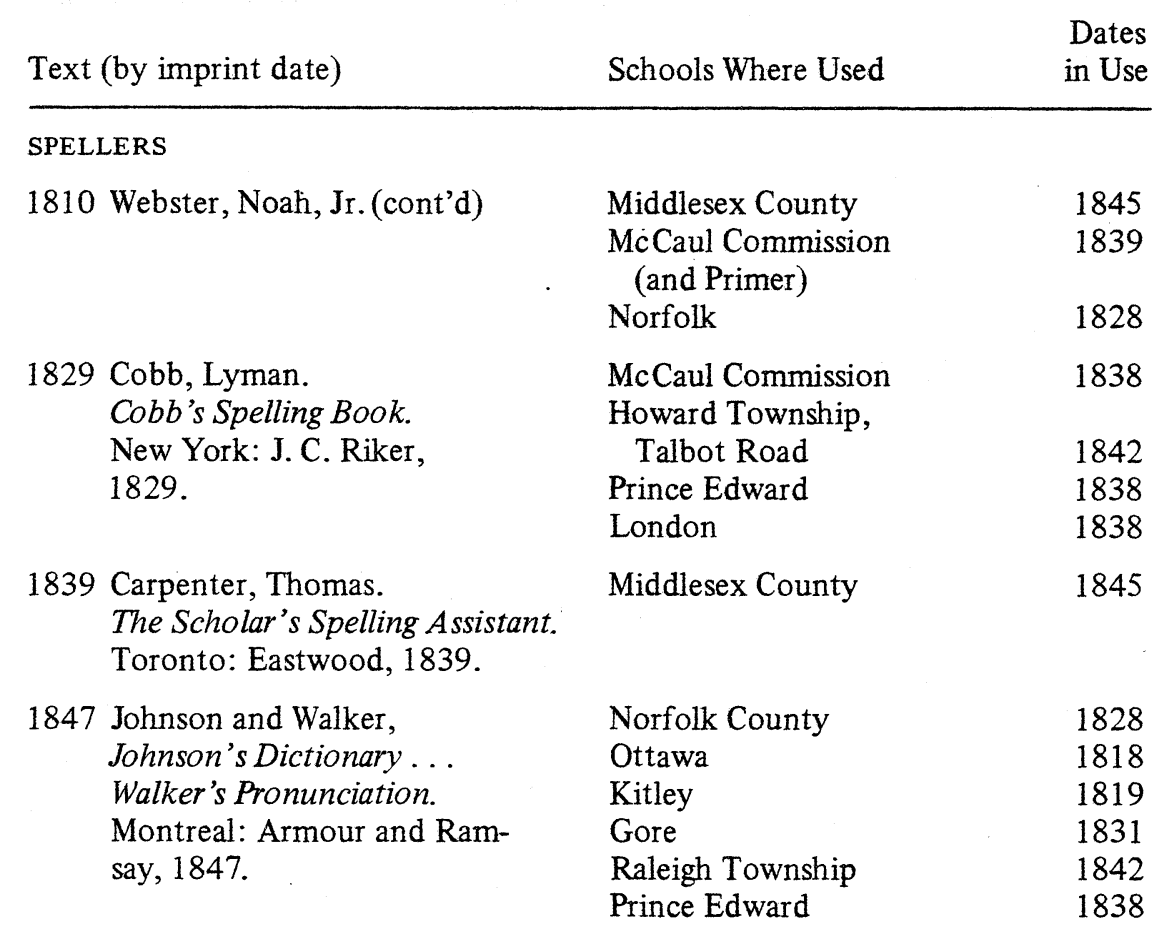

\section{Other Canadian Imprints}

1835 Mavor, William. The English Spelling Book. Montreal: Fabre, Perrault, 1835.

1837 Mavor, William. The English Spelling-Book. Toronto: H. H. Cunningham, 1837.

1843 Carpenter, Thomas. The Scholar's Spelling Assistant. Montreal: Campbell Bryson, 1843.

1845 Mavor, William. The English Spelling Book. Montreal: Campbell Bryson, 1845.

\section{GEOGRAPHIES}

1784 Morse, Jedidiah.

Ottawa

1818

Geography Made Easy. New

Gore

1831

Haven, Conn.: Meigs, Bowen

Wentworth County

$?$

\& Dana, 1784.

Norfolk

1828 


\section{GEOGRAPHIES}

1804 Goldsmith, Rev. J. (Sir Ralph Phillips).

Mentioned by McCaul

Commission

1839

An Easy Grammar of Geography.

Philadelphia: Benjamin Johnson, 1804.

1817 Cummings, J. A. An Introduction to Ancient and Modern Geography, on the Plan of Goldsmith and Guy. Boston: Cummings and Hilliard, 1817.

1828 Woodbridge, William C. Woodbridge's Rudiments of Geography on a New Plan. $9^{\text {th }}$ ed. Hartford, Conn.: Oliver D. Cooke and Co., 1828.

1830 Pinnock, William. A Comprehensive Grammar of Modern Geography and History. $2^{\text {nd }}$ ed. London: Poole \& Edwards [1830?].

1832 Olney, J. A Practical System of Modern Geography. $11^{\text {th }}$ ed. Hartford, Conn.: D. F. Robinson, 1832.

1843 Ewing, Thomas.

The Canadian School Geography. Montreal: Armour London

London and Ramsay, 1843.

London

1832

Prince Edward 1838

London 1838

McCaul Commission

1839

Mentioned by McCaul Commission

1839

\section{Other Canadian Imprints}

1843 Pinnock, William. A Catechism of Geography. $7^{\text {th }}$ Montreal ed. Montreal: Armour and Ramsay, 1843.

1845 Ewing, Thomas. The Canadian School Geography. Kingston: Atheneum, 1845. 


\section{HISTORIES}

1818 Pinnock, William. A Catechism of the History of Middlesex County America. London: Mentorian Press, 1818.

1843 Goldsmith, Oliver. Abridgement of the History of England. 15th ed. Edinburgh: Oliver and Boyd, 1843.

\section{LATINS}

1808 The Eton Latin Grammar. $4^{\text {th }}$

Ottawa ed. London: For Eton College, 1808.

1823 Ruddiman, Thomas and

John Hunter.

The Rudiments of the Latin

Tongue. $3^{\text {rd }}$ ed. Edinburgh:

Oliver and Boyd, 1823.

BIBLE

Ottawa Dist. (N.T.) 1818

County of York 1829

Gore (Bible \& N.T.) 1831

London (N.T.) 1832

London (N.T.) 1835

District of Newcastle $\quad 1823$

Raleigh Twsp. (N.T.) 1842

Lochiel Div. \#1 1842

Matilda School \#1 1842

Murray School Div. (N.T.) 1842

Murray School Div. (Bible) 1843

Johnstown (Bible, Testament) 1838

Bathurst (Bible and N.T.) 1838

Prince Edward 1838

Newcastle (N.T.) 1838

Ottawa (Testament) $\quad 1838$

Western (N.T.) 1838

London (O.T. \& N.T.) 1838

Norfolk (Testament) 1828

J. Donald Wilson 